Open Access

\title{
Psychological capital and entrepreneurial outcomes: the moderating role of social competences of owners of micro- enterprises in East Africa
}

\author{
Martin Mabunda Baluku ${ }^{1,3^{*}}$ (D), Julius Fred Kikooma', Edward Bantu ${ }^{2}$ and Kathleen Otto ${ }^{3}$
}

* Correspondence: mbaluku1@ gmail.com

'Department of Educational, Organizational and Social

Psychology, Makerere University, School of Psychology, P.O Box 7062, Kampala, Uganda

${ }^{3}$ Faculty of Psychology, Work and

Organizational Psychology

Gutenbergstr. 18,

Philipps-Universität, D-35032

Marburg, Germany

Full list of author information is

available at the end of the article

\begin{abstract}
Business success arises out of the total investments in the venture. This is not limited to tangible inputs such as financial capital, but on intangible resources as well. Entrepreneurship is a highly stressing occupation involving undertaking risks and often demanding workloads; hence requiring mental inputs (psychological capital). Moreover, the entrepreneurial job also involves doing business with other people of different statuses including investors, partners, customers, and employees; hence requiring the entrepreneur to exhibit a great deal of social competence to relate with others. Using two independent studies, we assess the contribution of psychological capital and social competence, as well as their interaction to entrepreneurial outcomes including performance (Study 1), and entrepreneurs' wellbeing, satisfaction, and commitment to their entrepreneurial career role (Study 2). Study 1 uses a sample of 102 owner-managers or managers of small companies in Uganda. In this study, entrepreneurs' social competence is measured as the relationship between entrepreneurs and their employees. Study 2 uses a sample of 228 young self-employed individuals in Uganda and Kenya; and operationalizes social competence via social intelligence. The results were consistent with our assumptions, highlighting the relevance of both psychological capital and social competence to entrepreneurial outcomes. Yet their interaction also has substantial impact on all outcomes examined in these studies.

Keywords: Commitment to entrepreneurship, Entrepreneurial outcomes, Performance, Psychological capital, Psychological resources, Satisfaction, Social competence, Well-being
\end{abstract}

\section{Background}

The entrepreneurial job involves creating new ventures and growing them into successful and sustainable enterprises. Each stage of the entrepreneurial process, however, presents daunting challenges; coupled with a dynamic competitive work environment and the risks undertaken (Baron, Franklin, \& Hmieleski, 2016; Umukoro \& Okurame, 2017). These can grossly affect several entrepreneurial outcomes including performance, entrepreneur's satisfaction, and wellbeing; consequently, reducing the potential for persisting in entrepreneurial activities. It is particularly the case for micro-enterprises in developing countries,

(c) The Author(s). 2018 Open Access This article is distributed under the terms of the Creative Commons Attribution 4.0 International License (http://creativecommons.org/licenses/by/4.0/), which permits unrestricted use, distribution, and reproduction in any medium, provided you give appropriate credit to the original author(s) and the source, provide a link to the Creative Commons license, and indicate if changes were made. 
where there are high rates of failure. On average, only about $34 \%$ of self-employed or micro-entrepreneurs are considered successful (Gindling \& Newhouse, 2014).

Whereas most of the challenges entrepreneurs are confronted with are external, such as economic conditions, therefore are outside the control of the entrepreneur (Albuquerque, Filho, Nagano, \& Junior, 2016); unsuccessful owners of small businesses tend to share similar characteristics (Gindling \& Newhouse, 2014). This suggests that entrepreneurs' abilities to cope with the demands of entrepreneurship play a critical role in achieving success. Two important intangible resources available to entrepreneurs (that is psychological capital and social capital) could help cope with the challenging role of entrepreneurship, thereby enhancing chances of success. Baron (2000) suggested that successful entrepreneurs tend to demonstrate high levels of mental and social competences. The paper, therefore, examines the contribution of these intangible resources to objective and subjective entrepreneurial outcomes. We also posit the two intangible resources have interactive effects on entrepreneurial outcomes, such that effect of psychological on each specific outcome is higher when an entrepreneur has levels of social competence.

Psychological capital is referred to as the "HERO within" (Luthans, 2012; Luthans \& Youssef-Morgan, 2017), indicating what individuals are likely to achieve with, as opposed to what they are likely to achieve without, positive psychological resources. This acronym also connotes the four positive cognitive resources constituting psychological capital: Hope, Efficacy, Resiliency, and Optimism. Based on the idea of resource caravans (Hobfoll, 2011), it is posited that these resources tend to work together resulting into superior performance; and go beyond what the entrepreneur has (financial capital); or knows (human capital); or whom the entrepreneur knows (social capital). The four psychological resources represent what an individual is; and particularly highlight the strengths rather than weaknesses of the person (Luthans, Luthans, \& Luthans, 2004). Psychological capital is generally related to positive work attitudes, superior performance and wellbeing in work situations (Chen et al., 2017a, b; Kim et al. 2017; Avey et al. 2011; Luthans et al., 2007a, b, c; Avey, Luthans, and Youssef 2010), thereby important for realization of both objective and subjective entrepreneurial outcomes (Baluku, Kikooma, \& Kibanja, 2016b; Baron et al., 2016).

In addition to the psychological resources, the ability to understand oneself and others is relevant for business leadership, customer handling, networking, teamwork, negotiation and conflict handling (Borg \& Johnston, 2013; Chin, Raman, Yeow, \& Eze, 2012; Humphrey, 2013). These should increase the likelihood of success among socially competence entrepreneurs. Social skills outlined by Albrecht (2006) including situational awareness, presence, clarity, and empathy (SPACE) are essential abilities for the entrepreneur; particularly in activities including relations with employees, customers, suppliers, and networks (Williams, 2008). Social ability is also related to the strength of ties of nascent entrepreneurs have with other people (Lans, Blok, \& Gulikers, 2015), which has implications for critical entrepreneurial tasks such as networking and marketing. The present study highlights the importance of two specific social competences, namely social intelligence, and relational capital. Whereas social intelligence concerns social information processing ability, social or interactional skills, and social awareness (Silvera, Martinussen, \& Dahl, 2001); relational capital denotes the mutual relationships between the firm or its owner and the people it interacts with (Bronzetti \& Veltri, 2013) including customers, employees, and suppliers. Therefore, social intelligence is a 
competence that enables individuals to behave appropriately in social situations. On the other hand, relational capital is the value nested in the nature of relationships, thus related but distinct from the concept of social capital (Still, Huhtamäki, \& Russell, 2013).

Despite the usefulness of psychological capital and social competences to business, it has been suggested that such intangible resources are poorly managed among young and micro enterprises, hence the need to continuously highlight the essentiality of these resources (Hormiga, Batista-Canino, \& Sánchez-Medina, 2011). In the present study, we test the assumption that the interaction of the two intangible resources further strengthens the likelihoods of achieving superior entrepreneurial outcomes. We particularly focus on subjective outcomes including performance, entrepreneur's satisfaction, their wellbeing, and commitment to the entrepreneurial role. Whereas literature emphasizes objective entrepreneurial outcomes, it has been noted that entrepreneurs seek more than economic benefits from their work (Baron et al., 2016), hence we emphasize the contribution of psychological capital and social competence to both objective outcomes (venture performance) and subjective outcomes (entrepreneur's satisfaction, wellbeing, and commitment to entrepreneurship work).

Two independent studies are reported in this paper. Study 1 examines the direct and interactive effects of psychological capital and social competence on entrepreneurial performance. In this study, social competence is measured with the concept of relational capital. However, the measurement focused on the relations between the firm owner or manager with the employees. Study 2 assesses the direct and interactional effects of psychological capital and social competence on subjective entrepreneurial outcomes among young self-employed individuals in two East African countries (Uganda and Kenya). In this study, social competence is measured with the concept of social intelligence. Measuring social competence with different concepts in the two studies serves to broaden the explaining variables (social intelligence vs. relational capital). Moreover, testing our assumptions with two samples aimed at replicating findings in a different sample as well as broadening the set of entrepreneurial outcomes that can be explained by psychological capital and social competences and their interaction.

\section{Theory and hypothesis development}

The study of success among microenterprises is dominated by the focus on economic parameters such as growth in sales, income and profits (e.g. Rindova, Barry, and Ketchen 2009; Baron, Franklin, and Hmieleski 2016; Robb and Fairlie 2009; Alom et al. 2016; Qureshi, Aziz, and Mian 2017) as well as growth in number of employees in the company (Alom et al., 2016; Baluku, Kikooma, \& Kibanja, 2016a). However, following calls to study entrepreneurial success beyond economic measures, there is increased research on subjective success, and thus increased focus on psychological processes and factors that are associated with entrepreneurial success. The idea is that some psychological attributes and states are important resources for entrepreneurial success and persistence (Baluku et al., 2016b; Duening, 2010; Patel \& Thatcher, 2014; Rauch, Braennback, \& Carsud, 2010).

Studies on entrepreneurial behavior and outcomes are increasingly applying psychological capital as an underlying mechanism that is associated with success (e.g. Baluku, Kikooma, \& Kibanja, 2016b; Baron et al., 2016; Jensen \& Luthans, 2006; Sarwar, Nadeem, \& Aftab, 2017). In the present study, we argue that psychological capital 
impacts on several objective and subjective outcomes of entrepreneurship. In addition, we argue that entrepreneurship as a career role is conducted in social settings, where amount and quality of social interactions are important to the execution of the job. Moreover, social relations contribute to motivation and persistence in activities, in line with the self-determination theory (Deci and Ryan 2015; Deci et al. 2001). Both self-determination and positive organizational behavior literature portray social relations and psychological capital as concepts that foster thriving, vitality, and psychological growth (Luthans et al., 2008a, b; Deci and Ryan 2000; Ryan 2009). This suggests that psychological capital and social competence have similar effects on entrepreneurs' behavior and are important for predicting entrepreneurial outcomes. The paper, grounded on psychological capital and social competence literature, examines the direct and interactive effects of positive personal resources, relational capital, and social intelligence on entrepreneurial outcomes and commitment to remain in the entrepreneurship role.

\section{The role of psychological Capital in Entrepreneurial Success}

Psychological capital is described as a state of mind, consisting of positive psychological strengths (Avey et al. 2011; Luthans and Youssef-Morgan 2017); therefore, it could be considered a positive mindset. Positive cognition is essential to an entrepreneurial mindset enabling individuals to learn from experiences and adjust to the dynamics of the business environment in order to achieve success (Haynie, Shepherd, Mosakowski, \& Earley, 2010). Facets of psychological capital, for example, optimism and self-efficacy, are essential for performance in cognitively related entrepreneurial tasks including innovation, and identification of opportunities (Arora, Haynie, \& Laurence, 2013; Gudmundsson \& Lechner, 2013; Hayek, 2012; Storey, 2011). Therefore, entrepreneurs apply psychological resources right from the start of the entrepreneurial process. This suggests that psychological capital is one of the cognitive investments that an entrepreneur will always be required to invest in sufficient amounts to achieve desired outcomes (Baluku et al., 2016b; Baron et al., 2016; Sarwar et al., 2017).

The construct of psychological capital (Goldsmith, Veum, \& Darity, 1997; Luthans et al., 2004) represents the psychological resources that individuals bring to their work. Based on positive psychology literature, psychological capital comprises of four resources including self-efficacy (confidence), optimism, hope and resilience (Luthans, Avolio, \& Avey, 2007a; Luthans et al., 2004). Whereas other constructs from positive psychology, such as trust (Page \& Donohue, 2004), have been suggested for inclusion as aspects of psychological capital; it is considered that only the four positive psychological resources are eligible for inclusion; based on the criteria that they are state-like and can be developed through specific interventions (Luthans \& Youssef-Morgan, 2017). Moreover, it is posited that these resources tend to move together (Luthans \& Youssef-Morgan, 2017) based on the assumptions of psychological resource caravans (Hobfoll, 2002, 2011). Consequently, an improvement in one of these resources may result in increase in the other(s). For example, evidence suggests that optimism and hope tend to lead to enhanced efficacy and resilience (Feldman \& Kubota, 2015; Storey, 2011).

Each of these components of psychological capital is critical resource at different stages of the entrepreneurial, therefore important for success. Self-Efficacy, or confidence, refers to an individual's belief in personal capacities to achieve a goal or complete a task 
(Bandura, 1997). It is a positive psychological resource that increases with mastery and vicarious experiences (Luthans et al., 2004). Applied to entrepreneurship, self-efficacy could be the force that drives individuals to undertake the risks of starting and managing a business venture (Boyd \& Vozikis, 1994) since it relates to confidence in one's own ability to mobilize the required resources and motivation to execute a given role or task in a given context (Stajkovic \& Luthans, 1998). High self-efficacy is related to the setting of challenging goals and the persistence in pursuance of those goals, hence it is a useful resource for entrepreneurial growth and performance (Hmieleski and Corbett 2008; Hmieleski and Baron 2008). Self-efficacy is also related to the ability to undertake risks (Bandura, 1997), which is an important part of the entrepreneurial job. Particularly, high self-efficacy is needed in identifying and exploiting opportunities, harnessing resources, and maneuvering the difficulties of establishing a business (Tumasjan \& Braun, 2012; Wilson, Kickul, \& Marlino, 2007).

Optimism is another aspect of psychological capital that is reported to have a substantial impact on the ability to do business. It regards an individual's expectations of positive outcomes or making positive attributions about the likelihood of success in the short or long term (Luthans, Youssef, and Avolio 2007c). People take the risk of investing money or other resources even when there are uncertainties because they expect positive returns on investment (Rigotti, Ryan, \& Vaithianathan, 2011). Hence, optimism is necessary for individuals to accept the risks of starting or growing a business venture (De Meza \& Southey, 1996; Storey, 2011; Trevelyan, 2008). The expectation of positive outcomes not only facilitates continuous investment in the growth of the business but also triggers resilience (Stagman-Tyrer, 2014), thus the ability to persist in the entrepreneurial role even at difficult business times. Optimism is also a cognitive resource that facilitates opportunity exploitation, creativity, and innovation (Storey 2011; Hmieleski and Baron 2009) resulting into superior entrepreneurial performance, as demonstrated by evidence from less developed and emerging countries (e.g. Chen, Joardar, and Wu 2017a; Chen et al. 2013).

Hope is the perception that one can achieve his/her goals, which facilitates the development of pathways and persistence towards achieving the set goals or desired outcome (Luthans et al., 2007a, b, c; Luthans and Jensen 2002). This derives from Snyder (2002) and Snyder et al. (1996)'s theorization of hope as consisting of three aspects: goals, agency, and pathways. The theory suggests that hope develops from way power (ability to develop plans and alternatives to achieve goals) and willpower/ agency (determination to act and maintain effort) and these complement each other in the pursuit of goals (Luthans 2012; Luthans, Avey, and Patera 2008a; Luthans and Jensen 2002). Setting goals and strategies to achieve them is one of the key tasks that entrepreneurs engage in during the lifetime of a business venture. Individuals higher on hope are able to adjust strategies when faced with difficulties; therefore, it is important for stimulating resiliency and persistence. Consequently, it is expected that entrepreneurs who are high in hope achieve superior outcomes. This ability is complemented by the resiliency resource. Resiliency is a psychological capability to cope with both negative and positive events as well as the ability to bounce back from adversity (Brandt, Gomes, and Boyanova 2011; Luthans, Youssef, and Avolio 2007c). It is also a resource that is useful in learning and thriving in difficult situations (Masten, 2001). This is important for coping with business stress related to risks, losses, competition, and resource constraints (Baron et al., 2016; Markman, Baron, \& Balkin, 2005). 
Overall, these four mental resources are theorized to combine to constitute a higher order construct of psychological capital (Luthans, Luthans, and Luthans 2004; Luthans and Youssef-Morgan 2017; Luthans 2012) that has increasingly been applied to explaining work attitudes and outcomes. In the field of entrepreneurship, existing research has indicated that psychological capital is an important predictor of performance and well-being of entrepreneurs; especially in dynamic and complex situations (Baron, Franklin, and Hmieleski 2016; Hmieleski and Carr 2008). The present study broadens the application of psychological capital to explain a wide range of entrepreneurial outcomes. Overall, the evidence presented in this review suggest that psychological resources are important for different entrepreneurial tasks and processes that including developing an interest in entrepreneurship, opportunity recognition, establishing the firm, creativity, innovation, developing and implementing business plans, as well as motivation for persistence. These consequently determine the level of objective and subjective success. We, therefore, hypothesize that:

H1. Psychological capital is positively related to entrepreneurial outcomes, including

(a) firm performance (Study 1),

(b) entrepreneur's satisfaction (Study 2),

(c) wellbeing (Study 2), and

(d) commitment to the entrepreneurial role (Study 2).

The role of social competences in entrepreneurial success

Several tasks of the entrepreneur are executed in the social space, where they interact with different stakeholders. Moreover, networking and cooperation, rather than competition, are emphasized for nascent and micro-enterprises to cope with the dynamic globalized business environment (Bøllingtoft, 2012). These tend to reduce costs of small enterprises (Agburu, Anza, \& Iyortsuun, 2017); and are consequently an antecedent of success. However, all of these require the application of social competences. Towards this direction, Markman and Baron (2003) propose that social competence plays an important role in entrepreneurial success.

Social competence, in the entrepreneurial field, concerns an entrepreneur's ability to effectively interact with people who are important to the firm. These include employees, customers, suppliers, investors, the community, and other stakeholders in the business. Social competence includes the ability to understand others, making good first impressions, adapting to a range of social situations and persuasiveness (Baron and Markman 2000). These enable entrepreneurs to build social capital and relational capital. We particularly assume that building relational capital is foundational for micro enterprises in establishing strong networks and collaborations; which in turn serve as sources of social capital. In this paper, we measure social competence using two social resources: relational capital (in Study 1) and social intelligence (in Study 2). The subsequent review focuses on the association of these resources with entrepreneurial success.

Relational capital is a construct denoting intangible resources available in the social relationships of the firm itself or of the business owner. It is a form of capital that represents benefits accruing from creating and maintaining relations with the major stakeholders and is usually reflected in customer loyalty and satisfaction as well as the 
firm's image with stakeholders such as financial entities and suppliers. This is summarized as the outward projection of the firm involving mutual relationships between the firm and the people or firms it interacts with (Bronzetti \& Veltri, 2013). Literature tends to portray relational capital as mainly resulting from relationships with customers (e.g. Bontis 1998; Stewart and Ruckdeschel 1998). However, the relations of the firm or its owner with other stakeholders could be equally important. For example, high-quality relations with suppliers tend to increase shared benefits between supplying and buying firms (Blonska, Storey, Rozemeijer, Wetzels, \& de Ruyter, 2013). Relational capital builds from social capital theory, and is,therefore, considered a facet of social capital (Blonska et al., 2013).

A key ingredient of relational capital is trust (Blonska et al., 2013; Liu, Ghauri, \& Sinkovics, 2010). Trust indicates that parties to a relationship are dependable, open, honest, vulnerable and identify with each other; as well as satisfaction and commitment to the relationship (Paine, Katie, \& Paine, 2003). This is essential to enabling the dedication of employees, hence leading to more effort put into their jobs and commitment to the firm. With regards to customers, relational capital implies customer loyalty (Bontis, 1998; Bronzetti \& Veltri, 2013). This ensures a sustained customer base and sustained sales. The relations with suppliers also imply higher negotiation power, and increased ability to buy on credit. Moreover, a good image and trust between the firm or the entrepreneur with investors and financial institutions strengthen the ability to solicit financing, hence important for the financial health of the company (Paine et al., 2003). This suggests that relational capital could be essential for the firm's growth and performance. Given that micro and small firms usually experience financial constraints (Kim, Aldrich, and Keister 2006; Artinger and Powell 2015; Tushabomwe-Kazooba 2006), they can gain competitive advantage and achieve success by deploying their social competences (Baron and Markman 2000; Liu, Ghauri, and Sinkovics 2010). Particularly, the literature shows that relations with customers and suppliers are associated with the success of the firm, especially in the first years of operation (Hormiga et al., 2011).

The above review indicates that relational capital is particularly important for achieving objective success as facilitated by customer loyalty and mutual relations with suppliers. The present study broadens the focus of relational capital by highlighting the impact of positive relations between entrepreneurs and their employees. Employees are the channel through which the company interacts with other stakeholders. Therefore the relationship between business owners and employees impacts on customer reactions to the company (Masterson, 2001). Moreover, it is reported that successful organizations are those that tend to treat employees as customers (Bowers \& Martin, 2007). Based on these views, we propose that relational capital generated internally from the mutual relationship between entrepreneurs or firm managers and employees is associated with superior entrepreneurial performance.

H2. Relational capital is positively associated with firms' entrepreneurial performance (Study 1).

Social intelligence is a social competence that concerns the ability to establish and maintain social contacts. It involves the ability to get along well with others and winning their cooperation; which consists of paying attention to other people's needs and interests, generosity attitude, and successful interactions with others (Albrecht, 2006). 
This social capability enables individuals to think and behave effectively in social situations or adjust to social environments (Albrecht, 2006; Kaukiainen et al., 1999; Riggio \& Reichard, 2008; Williams, 2008). To function appropriately in social situations, individuals require the wide range of abilities that make up social intelligence including empathy, communication, relationship management, self-expression, understanding social situations, self and interpersonal awareness, interpersonal problem solving, knowledge of social norms and scripts (Albrecht, 2006; Boyatzis \& Ratti, 2009; Kaukiainen et al., 1999; Riggio \& Reichard, 2008).

All these abilities are important in entrepreneurial situations. They are particularly essential for leadership and management (Boyatzis \& Ratti, 2009; Williams, 2008) of the business. This, in turn, could enhance relations between entrepreneurs and their employees, suppliers, and customers. In addition, social intelligence is related to emotional and cultural intelligence (Boyatzis \& Ratti, 2009; Crowne, 2009); yet the combination of these three bits of intelligence make individuals effective in interpersonal interactions. This consequently helps entrepreneurs in attracting and retaining customers as well as employees; and managing relations with partners (Williams, 2008). Therefore, social intelligence is an essential contributor to success in negotiating business deals, selling, motivating employees and customers which may improve firm performance and persistence.

This review indicates that social intelligence could enhance objective success. In the present study, we argue that social intelligence is also critical for achieving subjective entrepreneurial outcomes including the entrepreneur's satisfaction, well-being and willingness to persist in the entrepreneurial role. Ability to relate with others positively is known to reduce stress among entrepreneurs (Pollack, Vanepps, \& Hayes, 2012), thereby enhancing their well-being. Self-determination theory suggests that relatedness is one of the psychological needs that drive motivation and persistence (Deci \& Ryan, 2000; Milyavskaya \& Koestner, 2011). Specifically, the satisfaction of the need for relatedness, like other psychological needs, is antecedent for intrinsic motivation (Deci et al., 2001) which in turn is a determinant of superior work performance and satisfaction (Vansteenkiste et al., 2007). Therefore, the ability to maintain positive relations with stakeholders to the business could enhance the satisfaction and wellbeing of entrepreneurs, particularly for those who have a high need for relatedness. We, therefore, predict that;

H3. Entrepreneur's social intelligence is positively associated with:

(a) entrepreneur's satisfaction (Study 2),

(b) well-being (Study 2), and

(c) commitment to the entrepreneurial role (Study 2).

Psychological capital is related to cognitive abilities such as emotional intelligence (Sarwar et al., 2017) that enhances the quality of social interactions. Facets of psychological capital such as self-efficacy are important for individuals to enter and maintain social relations. This may be essential for attracting partners as well as maintaining positive relations with suppliers, investors, and customers, hence, improving chances of entrepreneurial success. Accordingly, in the present study, we predict that relational capital and social intelligence will moderate the positive effects of psychological capital 
on entrepreneurial outcomes. Previous research on moderators of the relationship between psychological capital and workplace behavior or outcomes show that the impact of psychological capital is affected by social relations concepts such as identity (Norman, Avey, Nimnicht, \& Graber Pigeon, 2010). For owners of microenterprises, social relations provide an opportunity to perform a number of entrepreneurial functions such as networking, fundraising, obtaining labor, and marketing. These facilitate entrepreneurial performance and offer an avenue for the application of the entrepreneurs' positive psychological resources. Therefore, the application of psychological capital to entrepreneurial activities and the impact it has on firm performance and entrepreneurs' wellbeing may partly depend on the quality of relations within the firm's social environment. We, therefore, propose that:

H4. The positive effects of psychological capital on entrepreneurial performance are strengthened by relational capital (Study 1).

H5. The positive effects of psychological capital on:

(a) entrepreneurs' satisfaction (Study 2),

(b) wellbeing (Study 2), and

(c) commitment to the entrepreneurial role is moderated by their social intelligence (Study 2).

\section{Empirical studies}

\section{Study 1: Impact of psychological capital and relational capital on entrepreneurial performance}

This study examines the direct and interactive effects of psychological capital and relational capital on entrepreneurial performance. In the theoretical review above, it was discussed that relational capital regards to the value of interactions of the firm with its social environment. This includes customers, suppliers, employers, and generally the community. In this study, relational capital is reflected by the quality of the relationship between the owner or manager of the business with his/her employees; focusing on the trust and collaboration between the two parties.

\section{Methods}

Sample The sample for this study comprised of owner-managers or managers of small enterprises in Uganda that participated in the Uganda 2015 edition of the Employer of the Year Award (EYA 2015) survey (Munene, Kikooma, \& Nansubuga, 2015). Only companies that are registered members of the Federation of Uganda Employers (FUE) participate in this bi-annual survey; which leads to the award of the employer of the year in the categories of small, medium enterprises, and large enterprises. The present study analysed data of owner-managers or chief executives in the small (or micro) enterprises category. The sample comprises of 102 individuals $(67.6 \%$ Male and $32.4 \%$ Female). Of these, $21.6 \%$ were owner-managers (owners who are also the chief executives of the firms) and $78.4 \%$ managers (chief executives who were not the owners of the firms). The participants varied significantly in their age, ranging from 18 to 74 years $(M=43.18$ years, $S D=12.84)$. 
Instruments To measure psychological capital, the psychological capital questionnaire (PCQ 24) (Luthans, Avolio, \& Avey, 2007a) was used. The questionnaire consists of 24 items relating to the four psychological resources. A sample item is "I feel confident analyzing a long-term problem to find a solution." Participants are required to indicate their level of agreement with the items on a 6-point Likert scale ( 1 = strongly disagree, and $6=$ strongly agree). This questionnaire showed high Cronbach's reliability for the present study $(\alpha=.90)$.

The measure for relational capital consisted of eight (8) most valid items from the scale used to measure relational human resources management in the EYA 2015 survey (Munene et al., 2015). These items particularly asked participants to evaluate relations and collaboration with their employees. Sample items include "There is a high level of trust between management and employees" and "My followers will go out of their way to help me solve my problems at work". These items were measured on a 6-point Likert scale requiring participants to indicate the extent to which the statements are true about the firm $(1=$ this is extremely untrue of this organization, and $7=$ this is extremely true of this organization). A high Cronbach reliability ( $\alpha=.89)$ was observed.

Entrepreneurial performance was assessed with six (6) most valid items from the firm performance instrument used in the EYA 2015 survey (Munene et al., 2015). These items reflect the owner's or manager's evaluation of the firm's performance. The items include: "My/this business has managed to develop new markets in the previous years," "My/this business has procured new equipment to improve on performance in the previous years," "In the last years, this business has understood the strengths of its competitors," "My/this business has achieved its most important goals in the previous years," "My/this business is successful compared to its competitors," and "In the past three years, this enterprise has provided funds for a new business startup." These items were measured on a 6-point Likert scale requiring participants to indicate the extent to which the statements are true about the business $(1=$ this is extremely untrue of this organization, and $7=$ this is extremely true of this organization). The questionnaire showed an acceptable Cronbach reliability coefficient $(\alpha=.76)$; given that .70 is considered the threshold (Nunnally, 1978).

\section{Results}

The means, standard deviations, reliability (Cronbach's alpha) coefficients, and correlations of the study variables are presented in Table 1. Findings on the relationships between psychological capital (H1a), relational capital (H2) and their interactive effects (H4) when it comes to explaining performance are presented in Table 2. To test these hypotheses, we applied moderated regression analysis using PROCESS macro (model 1) (Serrano-Cinca, Fuertes-Callén, \& Mar-Molinero, 2005). This model analyzes direct and conditional effects simultaneously. We also applied sample bootstrapping at 5000 in line with Hayes (2013). In the regression model, we included sex, age, and owner status (whether the respondent is owner-manager or manager); given that such personal factors affect entrepreneurial performance (e.g. Walker and Brown 2004).

In line with our assumptions, results in Table 2 indicate that psychological capital ( $B$ $=.33, p<.01)$ and relational capital $(B=.38, p<.001)$ are positively related to entrepreneurial performance. These results confirm $H 1 a$ and $H 2$. Hypothesis 4 predicted that 
Table 1 Descriptive statistics and variable intercorrelations (Study 1)

\begin{tabular}{|c|c|c|c|c|c|c|}
\hline & M & $S D$ & $a$ & 1 & 2 & 3 \\
\hline Age & 43.18 & 12.84 & & & & \\
\hline Psychological capital (1) & 5.95 & .73 & .90 & 1 & & \\
\hline Relational capital (2) & 5.30 & .90 & .89 & $.32^{* *}$ & 1 & \\
\hline Entrepreneurial performance (3) & 5.84 & .84 & .76 & $.39^{* * *}$ & $.43^{* * *}$ & 1 \\
\hline
\end{tabular}

the positive effects of psychological capital on entrepreneurial performance are moderated by relational capital, such that the impact of psychological capital is higher when relational capital is high. As shown in Table 2, we found significant interaction effects $(B=31, p<.05)$; with a significant increase in $\mathrm{R}^{2}$. Overall, the model explained $36 \%$ of entrepreneurial performance. As shown in the specific conditional effects in Table 2, as well as in Fig. 1, the effects of psychological capital on entrepreneurial performance were non-significant at a low level of relational capital. The effects were significant at average level of relational capital $(B=.33, C I=.12$ to .55$)$ and even stronger at high level of relational capital ( $B=.62, C I=.38$ to .85$)$. In addition, regarding the control variables, the findings indicate that owner status had significant effects on entrepreneurial performance $(B=.18, p<.05)$ indicating that firms managed by their owners tend to have lower performance than those managed by hired managers. However, the study used a subjective measure and therefore caution should be exercised in applying this result.

Study 2: Impact of psychological capital and social intelligence on entrepreneurial outcomes of young self-employed individuals

Study 2 focuses on the impact of psychological capital and social competence on three entrepreneurial outcomes: entrepreneurs' satisfaction, well-being, and commitment to

Table 2 Regression model for effects on entrepreneurial performance (Study 1)

\begin{tabular}{|c|c|c|c|c|c|}
\hline & \multirow[t]{2}{*}{$B$} & \multirow[t]{2}{*}{ SE } & \multirow[t]{2}{*}{$t$} & \multicolumn{2}{|c|}{$95 \% \mathrm{Cl}$} \\
\hline & & & & $\mathrm{LLCl}$ & ULCI \\
\hline Constant & 5.08 & .32 & $16.07^{* * *}$ & 4.45 & 5.71 \\
\hline Sex & -.13 & .20 & -.64 & -.52 & .26 \\
\hline Age & .17 & .10 & 1.69 & -.03 & .37 \\
\hline Owner status & .18 & .08 & $2.11^{*}$ & .01 & .34 \\
\hline Psychological capital (PsyCap) & .33 & .11 & $3.06^{* *}$ & .12 & .55 \\
\hline Relational capital (RelCap) & .38 & .10 & $3.78^{* * *}$ & .18 & .58 \\
\hline PsyCap × RelCap & .31 & .15 & $2.15^{*}$ & .02 & .60 \\
\hline Model summary & \multicolumn{5}{|c|}{$R^{2}=.36, F(6,95)=13.74^{* * *}$} \\
\hline$\Delta R^{2}$ due to interaction & \multicolumn{5}{|c|}{$\Delta R^{2}=.05, F(1,95)=4.63^{*}$} \\
\hline \multicolumn{6}{|c|}{ Conditional effects of PsyCap at levels of RelCap } \\
\hline Low RelCap & .05 & .21 & .23 & -.37 & .47 \\
\hline Average RelCap & .33 & .11 & $3.06^{* *}$ & .12 & .55 \\
\hline High RelCap & .62 & .12 & $5.23^{* * *}$ & .38 & .85 \\
\hline
\end{tabular}

${ }^{*} p<.05 ;{ }^{* *} p<.01 ;{ }^{* * *} p<.001$; Sample bootstrap $=5000$

Sex $(0=$ male, $1=$ female $)$

Owner status $(0=$ owner-manager, $1=$ manager $)$ 
the entrepreneurial role. The study was conducted among young self-employed individuals in two East African countries; Uganda and Kenya. In this study, social competence is reflected by the social intelligence of the entrepreneur.

\section{Methods}

Sample Survey data was collected from a sample of young educated self-employed individuals. Participants included individuals who recently graduated from secondary school (21.1\%), technical colleges (24.5\%) and university (54.4\%); all engaged in entrepreneurial projects as their main form of employment. Young self-employed individuals were invited to participate in the study through youth business forums such as training workshops and meetings in Uganda and Kenya. A total of 228 young self-employed persons (131 Ugandan and 97 Kenyan) aged 17 to 30 years completed the survey questionnaire (Mean age $=24.09$ years, $\mathrm{SD}=2.74$ ); of which 143 were males and 145 females. Participants had been in running their entrepreneurial projects for a period ofless than a year (24.1\%), $1-2$ years $(40.4 \%), 2-5$ years $(32.9 \%)$, over 5 years $(2.6 \%)$. The majority of the participants reported having established their businesses using funds from personal savings or non-refundable contributions from family and friends (59.6\%). The remaining $40.4 \%$ funded their startups through loans obtained from micro-credit institutions and individual money lenders.

Instruments Psychological capital was measured with the same instrument as that used in Study 1. The items were measured on a 6 -point Likert scale $(1=$ strongly disagree, to $6=$ strongly agree). The questionnaire showed good internal consistency (Cronbach's $\alpha=.83$ ). Social intelligence was measured using the Tomso Social Intelligence Scale - TSIS (Silvera, Martinussen, \& Dahl, 2001). The scale measures three facets including social information processing, social skills, and social awareness. A sample item is "I am good at getting on good terms with new people". The items were

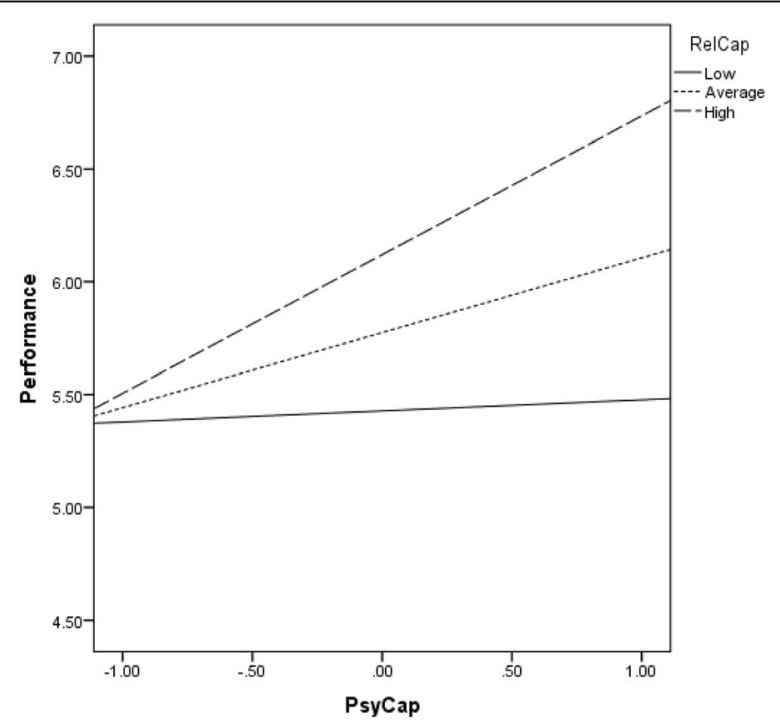

Fig. 1 Interactive effects of psychological capital and relational capital on entrepreneurial performance 
measured on a 6 -point Likert scale $(1=$ strongly disagree, to $6=$ strongly agree). This questionnaire showed good reliability for the study sample $(\alpha=.89)$.

To measure entrepreneurs' satisfaction, five items from the revised sub-scales of the short form of the Minnesota satisfaction questionnaire (Hirschfeld, 2000) were selected. Only items classified as measuring intrinsic satisfaction were used, given that most of the items relating to extrinsic satisfaction aspects such as satisfaction with pay and supervision may not be applicable to self-employed people or entrepreneurs. A sample item is "I am satisfied with the success of my business". The items were measured on a 5-point Likert scale ranging from 1 (strongly disagree) to 5 (strongly agree). An acceptable reliability $(\alpha=.71)$ was observed.

To measure subjective well-being, two-items were adopted from the psychological and subjective well-being questionnaire (Samman, 2007). The two items adopted for this study measure overall life satisfaction and happiness. The items are "In general, would you say that you are satisfied with your life" (responses include: very satisfied, fairly satisfied, not very satisfied, and not at all satisfied); and "Taking all things together, would you say you are" (responses include: very happy, rather happy, not very happy, not at all happy). These items had a good reliability $(\alpha=.87)$.

Commitment to the entrepreneurial role was measured with four items adapted from the career commitment scale (Blau, 1985, 1988). This scale is designed to measure an individuals' commitment to their occupations. A sample item is "I am committed to making a career in entrepreneurship". Items were measured on a 5-point Likert scale ranging from 1 (strongly disagree) to 5 (strongly agree). A high-reliability coefficient $(\alpha=.94)$ was observed.

\section{Results}

Descriptive statistics and correlations are shown in Table 3. To test for the effects of psychological capital and social intelligence on entrepreneurial outcomes (including entrepreneurs' satisfaction, subjective well-being, and commitment to their entrepreneurial role), we applied a moderated regression using the same procedure as that used in Study 1. A separate model was computed for each outcome (as shown in Table 4). In each of the regression models, we controlled for the effects of sex, age, country, education level, time spent in self-employment, and source of funding used to establish the business. Previous research has linked these personal factors to business success and failure (e.g. Lee \& Tsang, 2001; Walker \& Brown, 2004).

Table 3 Descriptive statistics and variable intercorrelations (Study 2)

\begin{tabular}{|c|c|c|c|c|c|c|c|c|}
\hline & M & SD & a & 1 & 2 & 3 & 4 & 5 \\
\hline Age & 24.09 & 2.74 & & & & & & \\
\hline Time in SE & 2.23 & 1.61 & & & & & & \\
\hline Psychological capital (1) & 4.53 & .41 & .83 & 1 & & & & \\
\hline Social intelligence (2) & 5.08 & .67 & .89 & $.56^{* * *}$ & 1 & & & \\
\hline Subjective wellbeing (3) & 2.25 & .67 & .87 & $.62^{* * *}$ & $.52^{* * *}$ & 1 & & \\
\hline Satisfaction (4) & 3.80 & .45 & .71 & $.50^{* * *}$ & $.47^{* * *}$ & $.46^{* * *}$ & 1 & \\
\hline Commitment (5) & 2.76 & 1.05 & .94 & $.39^{* * *}$ & $.21^{* *}$ & $.49^{* * *}$ & $.39^{* * *}$ & 1 \\
\hline
\end{tabular}

${ }^{* *} p<.01 ;{ }^{* * *} p<.001$ 
Table 4 Regression model for effects on entrepreneur's satisfaction, wellbeing, and commitment (Study 2)

\begin{tabular}{|c|c|c|c|c|c|c|c|c|c|c|c|c|c|c|c|}
\hline & \multicolumn{5}{|c|}{ Satisfaction } & \multicolumn{5}{|c|}{ Subjective wellbeing } & \multicolumn{5}{|c|}{ Commitment } \\
\hline & \multirow[t]{2}{*}{$\bar{B}$} & \multirow[t]{2}{*}{ SE } & \multirow[t]{2}{*}{$t$} & \multicolumn{2}{|c|}{$95 \% \mathrm{Cl}$} & \multirow[t]{2}{*}{$B$} & \multirow[t]{2}{*}{ SE } & \multirow[t]{2}{*}{$t$} & \multicolumn{2}{|c|}{$95 \% \mathrm{Cl}$} & \multirow[t]{2}{*}{$B$} & \multirow[t]{2}{*}{ SE } & \multirow[t]{2}{*}{$t$} & \multicolumn{2}{|c|}{$95 \% \mathrm{Cl}$} \\
\hline & & & & $\mathrm{LLCl}$ & $U L C I$ & & & & $\mathrm{LLCl}$ & ULCI & & & & $\overline{\mathrm{LCl}}$ & $U L C I$ \\
\hline Constant & 3.66 & .22 & $16.55^{* * *}$ & 3.22 & 4.10 & 2.49 & .30 & $8.40^{* * *}$ & 1.90 & 3.07 & 2.70 & .50 & $5.36^{* * *}$ & 1.71 & 3.69 \\
\hline Sex & -.02 & .05 & -.41 & -.13 & .08 & -.08 & .07 & -1.16 & -.23 & .06 & -.33 & .12 & $-2.68^{* *}$ & -.57 & -.09 \\
\hline Age & -.01 & .06 & -.05 & -.12 & .11 & .06 & .08 & .68 & -.11 & .22 & .40 & .14 & $2.80^{* *}$ & .12 & .68 \\
\hline Country & .07 & .05 & 1.20 & -.04 & .17 & -.21 & .07 & $-3.23^{* *}$ & -.34 & -.08 & -.56 & .11 & $-4.95^{* * *}$ & -.78 & -.34 \\
\hline Education level & -.01 & .02 & -.53 & -.05 & .03 & -.00 & .03 & -.07 & -.06 & -.05 & -.04 & .06 & -.74 & -.15 & .07 \\
\hline $\begin{array}{l}\text { Time spent in } \\
\text { SE }\end{array}$ & .08 & .04 & $2.02^{*}$ & .01 & .16 & .01 & .05 & .18 & -.09 & .11 & .04 & .09 & .41 & -.14 & .21 \\
\hline $\begin{array}{l}\text { Source of } \\
\text { funding }\end{array}$ & -.06 & .05 & -1.26 & -.15 & .03 & -.03 & .06 & -.40 & -.15 & .10 & .07 & .11 & .61 & -.15 & .28 \\
\hline $\begin{array}{l}\text { Psychological } \\
\text { capital } \\
\text { (PsyCap) }\end{array}$ & .38 & .10 & $3.73^{* * *}$ & .18 & .57 & .71 & .15 & $4.74^{* * *}$ & .42 & 1.01 & .80 & .22 & $3.67^{* * *}$ & .37 & 1.24 \\
\hline $\begin{array}{l}\text { Social } \\
\text { intelligence } \\
\text { (SQ) }\end{array}$ & .24 & .06 & $3.97^{* * *}$ & .12 & .36 & .28 & .09 & $3.00^{* *}$ & .10 & .47 & .01 & .13 & .08 & -.24 & .26 \\
\hline PsyCap $\times$ SQ & .28 & .08 & $3.48^{* * *}$ & .12 & .44 & .28 & .13 & $2.11^{*}$ & .02 & .57 & .78 & .18 & $4.30^{* * *}$ & .42 & 1.13 \\
\hline $\begin{array}{l}\text { Model } \\
\text { summary }\end{array}$ & \multicolumn{5}{|c|}{$R^{2}=.37, F(9,218)=23.85^{* * *}$} & \multicolumn{5}{|c|}{$R^{2}=.49, F(9,218)=22.05^{* * *}$} & \multicolumn{5}{|c|}{$R^{2}=.41, F(9,218)=29.69^{* * *}$} \\
\hline $\begin{array}{l}\Delta R^{2} \text { due to } \\
\text { interaction }\end{array}$ & \multicolumn{5}{|c|}{$\Delta R^{2}=.03, F(1,218)=.12 .12^{* * *}$} & \multicolumn{5}{|c|}{$\Delta R^{2}=.02, F(1,218)=4.47^{*}$} & \multicolumn{5}{|c|}{$\Delta R^{2}=.5, F(1,218)=18.50^{*}$} \\
\hline \multicolumn{16}{|c|}{ Conditional effects of PsyCap at levels of SQ } \\
\hline Low SQ & .19 & .13 & 1.48 & -.06 & .44 & .52 & .21 & $2.45^{*}$ & .10 & .94 & .29 & .26 & 1.09 & -.23 & .81 \\
\hline Average SQ & .38 & .10 & $3.73^{* * *}$ & .18 & .57 & .71 & .15 & $4.74^{* * *}$ & .42 & 1.01 & .80 & .22 & $3.67^{* * *}$ & .37 & 1.24 \\
\hline High SQ & .56 & .10 & $5.80^{* * *}$ & .37 & .75 & .90 & .12 & $7.25^{* * *}$ & .66 & 1.15 & 1.32 & .24 & $5.61^{* * *}$ & .86 & 1.78 \\
\hline
\end{tabular}

It was proposed that psychological capital of entrepreneurs will be positively associated with their satisfaction $(H 1 b)$, subjective well-being $(H 1 c)$, and commitment to stay in entrepreneurship $(H 1 d)$. As indicated in Table 4, psychological capital had positive significant relationships with entrepreneurs' satisfaction $(B=.38, p<.001)$, subjective well-being $(B=.71, p<.001)$ and commitment to entrepreneurial role $(B=.80, p<.001)$. Hypotheses $3 a, 3 b$ and $3 c$ proposed that social intelligence of entrepreneurs will also be positively associated with these entrepreneurial outcomes. Results of regression models in Table 4 further indicate that social intelligence was positively and significantly related to entrepreneurs' satisfaction $(B=.24, p<.001)$ and subjective well-being $(B=.36$, $P<.001$ ), but was not related to commitment to stay in entrepreneurship. Therefore, $H 3 a$ and $H 3 b$ are supported, but $H 3 c$ is not confirmed.

Hypotheses $5 a, 5 b$, and $5 c$ predicted that the positive effects of psychological capital on entrepreneurial outcomes are moderated by entrepreneurs' social intelligence. Consistent with these predictions; results in Table 4 further reveal positive significant interaction effects of psychological capital and social intelligence on entrepreneurs' job satisfaction (B $=.28, \mathrm{p}<.001)$, subjective well-being $(\mathrm{B}=.28, p<.05)$, and commitment to stay in entrepreneurship $(\mathrm{B}=.78, \mathrm{p}<.001)$. The pattern of interactions is shown in conditional effects 


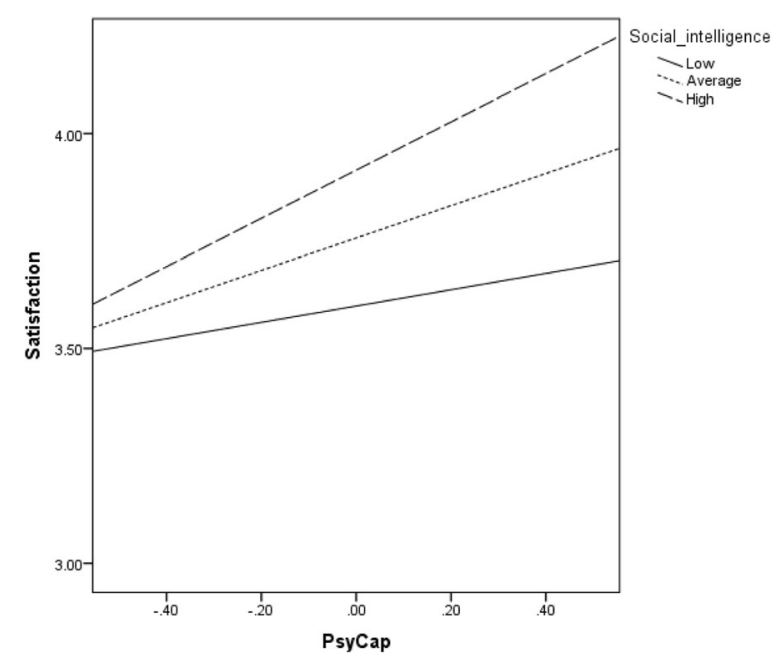

Fig. 2 Interactive effects of psychological capital and social intelligence on entrepreneur's satisfaction

in Table 4; while Figs. 2, 3 and 4 illustrate that the impact of psychological capital on each of these outcomes are strongest at a high level of social intelligence. In contrast, we found that psychological capital has only marginal effects on these entrepreneurial outcomes at low levels of social intelligence.

\section{Discussion}

The entrepreneurial process does not start and end with the founding of a new business (DeTienne, 2010). Ensuring success and survival of the new enterprise is part of the process, and majorly a responsibility of the entrepreneur. Success accrues from total investments an entrepreneur brings to the venture, including intangible inputs such as effort and psychological resources. The purpose of the studies reported in this paper was to investigate the direct and interactive effects of intangible resources, namely psychological

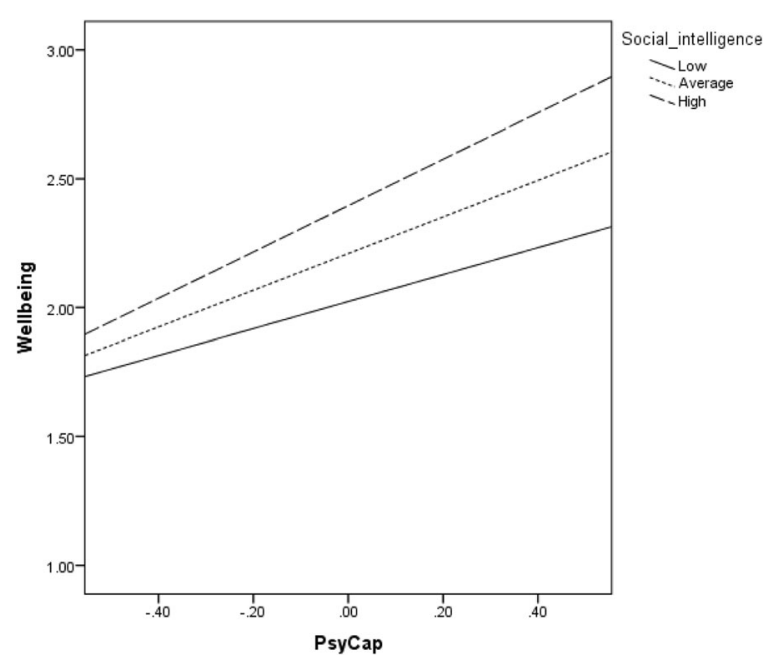

Fig. 3 Interactive effects of psychological capital and social intelligence on entrepreneur's subjective wellbeing 


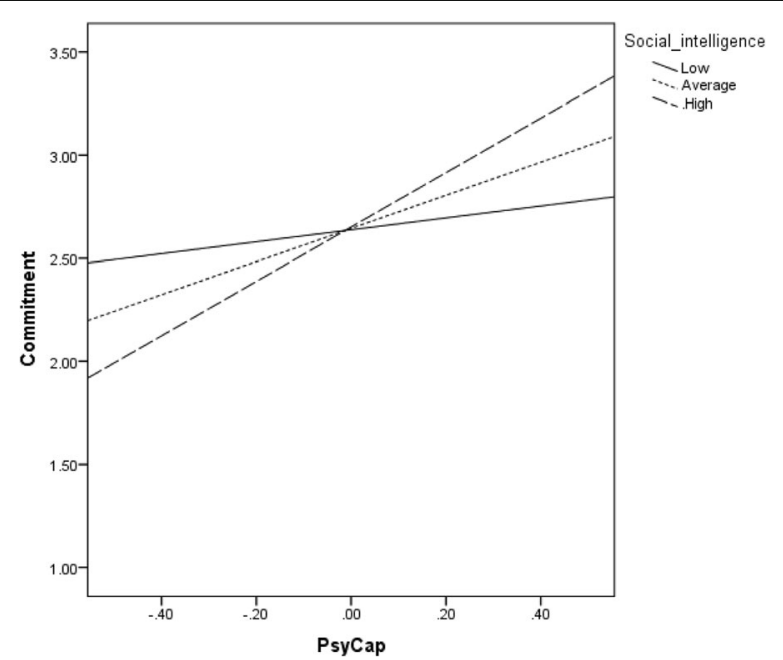

Fig. 4 Interactive effects of psychological capital and social intelligence on commitment to entrepreneurial role

capital and social competence, on different entrepreneurial outcomes including firm performance, entrepreneurs' satisfaction, wellbeing, and commitment to the entrepreneurial job. The findings of the present studies indicate that the assumption that psychological capital and social competence are essential for achieving positive entrepreneurial outcomes was confirmed.

Findings of Study 1 specifically reveal that psychological capital has significant effects on entrepreneurial performance of small and micro businesses. High psychological capital implies that the individual has a high level of confidence/ efficacy, hope, resilience, and optimism. Extant literature shows that these resources are important for recognition and exploitation of entrepreneurial opportunities, harnessing resources for investment, taking risks, developing strategies for achieving business goals, as well as coping with stress associated with business (Ardichvili, Cardozo, \& Ray, 2003; Baluku et al., 2016b; Baron, 2006; Baron et al., 2016). Investing these psychological resources into business, therefore, enhances the chances for success both in terms of performance and subjective outcomes. Entrepreneurs with high psychological capital are more likely to make continuous investments in their businesses due to high optimism. They could also be more willing to invest even in high-risk business opportunities, tolerate such risks and remain resilient when faced with challenges (Baron et al., 2016). The creativity associated with high psychological capital (Rego, Sousa, Marques, \& Cunha, 2012; Sweetman, Luthans, Avey, \& Luthans, 2011) also enables entrepreneurs with strong psychological resources to have superior performance.

We also found support for our hypothesis that relational capital is positively related to entrepreneurial performance. In Study 1, we specifically measured relational capital with the quality of relations between the business owner or manager and employees. The findings indicate that those reporting higher entrepreneurial performance were also more likely to report high relational capital. High relational, in this study, represents the quality of the relationship between the entrepreneur and his or her employees; which is characterized by the mutual trust (Blonska et al., 2013). This kind of relationship is antecedent for workers' positive perception and behavior towards the 
firm (Masterson, 2001). Consequently, such positive relations between entrepreneur and employees may have a positive impact on the performance of the firm. Also in line with the assumption that firms that treat employees as customers are more successful (Bowers \& Martin, 2007), the quality of relations between business owner or manager and workers is often reflected in their behaviors towards customers and other stakeholders they interact with. This does not only improve the image of the firm among its stakeholders but may also facilitate customer loyalty, consequently improving the performance of the firm.

The studies presented in this paper also shed light on the role of psychological and social capitals in achieving subjective entrepreneurial outcomes. Findings of Study 2 specifically indicate that psychological capital has positive effects on entrepreneurs' satisfaction and well-being. This result reaffirms previous research reporting psychological capital to be negatively related to stress and positively associated with the well-being of entrepreneurs (Baron et al., 2016). Entrepreneurship is a complex task that is executed in the highly competitive business environment. Moreover, small business or self-employment is sometimes considered a precarious job (Kottwitz, Hünefeld, Frank, \& Otto, 2017). It would, therefore, be expected that entrepreneurs would report low satisfaction and wellbeing. On the contrary, some entrepreneurs tend to be satisfied with their entrepreneurial job and have higher wellbeing, partly attributed to high levels of psychological capital (Baron et al., 2016). The mental resources constituting psychological capital are useful in coping with business stress and work demands, maintaining vigor, finding solutions to problems, and recovering from business challenges. These may translate into high satisfaction and wellbeing. Moreover, our results also indicate that psychological capital is related to entrepreneurial performance, which further boosts the entrepreneur's satisfaction.

Regarding the association between social competence and subjective entrepreneurial outcomes, results of Study 2 show that social intelligence has positive effects on entrepreneurs' satisfaction and well-being. Individuals with high social intelligence have the ability to interact effectively with others (Albrecht, 2006). This is an important competence for entrepreneurs to build social networks, to relate to their employees, suppliers, and customers; all of which are important for entrepreneurial success. But also enhance the wellbeing of the entrepreneur in line with self-determination theory (Deci \& Ryan, 2000) given that these relations enable entrepreneurs to gratify their need for relatedness.

Whereas each of these intangible resources is essential for an entrepreneur, an individual who has both high psychological capital and high social competence might enjoy even higher levels of success. The findings of Study 1 revealed that the interaction between psychological capital and relational capital has significant effects on entrepreneurial performance. The findings of Study 2 further show significant effects of interactions between psychological capital and social intelligence on subjective outcomes (satisfaction and wellbeing). Specifically, entrepreneurs reported high entrepreneurial performance, satisfaction, and wellbeing when both psychological well-being and relational capital or social intelligence were high. Our findings indicate that these social competencies support the meaningful application of one's psychological resources. For example, an entrepreneur with high psychological capital is likely to use the social networks for marketing, fundraising, and gaining information on investment opportunities. Strong social competence is also more useful if the entrepreneur has the psychological strength to identify and exploit opportunities in social relationships. 
If entrepreneurs are to enjoy the benefits of their entrepreneurial roles, persistence is important, given that the benefits of business accrue in the long-term than in the short term. We, therefore, tested the interative effects of psychological capital and social competence (social intelligence) on the commitment to stay in entrepreneurship or self-employment. Our findings indicate that only psychological capital is relevant for readiness to stay in entrepreneurial roles. However, our findings (Table 4) show that the interaction between these intangible resources accounts for even a greater variance in commitment to entrepreneurial roles. Resources that constitute psychological capital including self-efficacy, optimism, and resilience are associated with persistence in challenging situations and tasks (Baron \& Markman, 2000; Luthans \& Youssef-Morgan, 2017). When faced with challenges in business, entrepreneurs with high psychological capital have the ability to develop alternative plans of actions and act on them; and tend to have strong belief that their ventures will achieve the set goals. This enables them to remain committed to the entrepreneurial job. Moreover, for those with both high psychological capital and social competence, their psychological strength enables them to use available networks to harness resources, undertake wider marketing, as well as developing alternative strategies; which are important for long terms survival of the business.

\section{Conclusion}

The findings of the present studies contribute to the understanding of the role of intangible resources in entrepreneurship. They confirm the assumption that entrepreneurial success does not only accrue from tangible resources. But also from psychological and social resources that the entrepreneur brings to the venture. Psychological capital and social competence are specifically important resources for entrepreneurial success. They enable entrepreneurs to flourish despite the challenges and demands of their job. These intangible resources that are nested in entrepreneurs' personal attributes facilitate opportunity recognition, decision making, networking, business negotiations, coping with stress, harnessing resources and dealing with different stakeholders; which are important tasks of the entrepreneur that lead to success. Moreover, stronger psychological capital and social competence also increase the likelihood of persisting in an entrepreneurial role. The ability to remain optimistic, hopeful, resilient and confident, as well as the ability to effectively interact with others, are recipes persisting in entrepreneurial activities. In practical terms, therefore, the results of the studies presented in this paper suggest that assisting entrepreneurs to strengthen their psychological strength and social competence is essential. There are techniques that have been suggested for improving psychological capital and social competence (Baron \& Markman, 2000; Luthans \& Youssef-Morgan, 2017). Supporting entrepreneurs to strengthen their psychological and social competences can, therefore, be important for promoting successful entrepreneurship.

\section{Limitations and suggestions for further research}

The study has a number of limitations that should be taken into consideration. First, although our findings show that psychological capital and social competence are positively related to entrepreneurial outcomes including performance, satisfaction, wellbeing, and 
commitment to remain in entrepreneurship, we did not investigate the mechanisms through which these positive effects are transmitted. Previous research has noted the contribution of psychological capital and social competence to opportunity recognition, creating alliances, and resistance to stress (Miller, 2012). These are potential mediators of the linking between psychological resources and entrepreneurial success. The possible mediating and moderating processes that facilitate the positive impact of psychological capital and social competence on entrepreneurial outcomes need to be examined.

Another limitation of the present findings is that they are based on data obtained through self-reports. Entrepreneurs reported on their own psychological capital and social competencies as well as on the outcomes examined. This leads to the possibility of social desirability bias (Deci \& Ryan, 2000). Moreover, specifically Study 1 was conducted with a relatively small sample of entrepreneurs in a developing country, hence the sample size might not have helped to offset the challenge of using self-assessment. However, given that the two studies reveal similar findings, this may suggest that findings are not affected by this bias. Nonetheless, caution in application and generalization of the results is required. It would also be interesting for future studies to make cross-cultural examinations of the impact of psychological capital and social competence on entrepreneurial outcomes.

In the present studies, examination of social competence was operationalized with a focus on relational capital (Study 1) and social intelligence (Study 2). Moreover, the measurement of relational capital was confined to focus on the quality of relations between the business owner-manager and the workers. However, relational capital includes the value of relations with different stakeholders, particularly customers. This further calls for caution in the application of the results of the present studies. Future studies should pay attention to the aspects of relations with customers, suppliers, and community. Relations and mutual trust with these stakeholders may be essential for different aspects of entrepreneurial success. Regarding psychological capital, the specific contributions of each facet should be investigated. Such studies may be essential for supporting nascent entrepreneurs.

\section{Acknowledgements}

We acknowledge the support from Makerere University School of Psychology, Department of Educational, Social, and Organizational Psychology. We also thank Federation of Uganda Employers and her member organizations that participated in the survey. The authors also acknowledge the contributions of Dr. Peter Onderi and Ms. Moreen Mitch Agalo during data collection process.

\section{About the authors}

1. Martin Mabunda Baluku (PhD), is a Lecturer at Makerere University, department of Educational, Organizational and Social Psychology. His current research interests are: psychological attributes and entrepreneurship; career development; the psychology of cheating and corruption; retirement and psychological wellbeing; and organizational politics and change.

2. Kathleen Otto (PhD), is a Professor of Organizational and Work Psychology at Philipps Universität-Marburg, Germany. Her research interests are job insecurity; organizational justice; self-employment; and career success.

3. Julius Fred Kikooma (PhD), is Associate Professor of Organizational Psychology and Dean of Makerere University School of Psychology. His current research interests are Higher Education, Corporate Realities, Employment of University Graduates, Innovation and Entrepreneurship, Family Business, and Consumerism and Identity.

4. Edward Bantu (PhD), is a senior lecturer at the Kisii University, Kenya and a practicing counselor. His research interests are career transitions, career development, human resources development, and psychological wellbeing. 


\section{Availability of data and materials}

The dataset used for Study is available from Makerere University School of Psychology, Department of Educational, Social, and Organizational Psychology. Data used for Study 2 is available from the corresponding author on reasonable request.

\section{Authors' contributions}

$M M B$, is the main author of the manuscript. He drafted the manuscript and ensured that it's complete. Also coordinating the inputs of all the authors. JFK, was responsible for conducting Study 1. He is the principal investigator for the project from which Study 1 was drawn. He also participated in the analysis and interpretation of Study 1 data. $E B$, participated in conducting Study 2 specifically collecting data from Kenya. He also participated in analyzing and interpreting data for this study. KO, provided overall oversight; providing the technical advice and support in conducting Study 2 and also during the development of the manuscript. She also edited the manuscript to ensure appropriateness and completeness. All authors read and approved the final manuscript.

\section{Competing interests}

The authors declare that they have no competing interests.

\section{Publisher's Note}

Springer Nature remains neutral with regard to jurisdictional claims in published maps and institutional affiliations.

\section{Author details}

'Department of Educational, Organizational and Social Psychology, Makerere University, School of Psychology, P.O Box 7062, Kampala, Uganda. ${ }^{2}$ Faculty of Education \& Human Resource, Kisii University, P.O Box 408 - 40200, Kisii, Kenya. ${ }^{3}$ Faculty of Psychology, Work and Organizational Psychology Gutenbergstr. 18, Philipps-Universität, D-35032 Marburg, Germany.

Received: 4 January 2018 Accepted: 30 August 2018

Published online: 08 September 2018

\section{References}

Agburu, J. I., Anza, N. C., \& lyortsuun, A. S. (2017). Effect of outsourcing strategies on the performance of small and medium scale enterprises (SMEs). Journal of Global Entrepreneurship Research, 7(1), 26. https://doi.org/10.1186/s40497-017-0084-0.

Albrecht, K. (2006). Social intelligence: The new science of success. San Francisco, CA: Jossey-Bass.

Albuquerque, A. F., Filho, E. E., Nagano, M. S., \& Junior, L. A. P. (2016). A change in the importance of mortality factors throughout the life cycle stages of small businesses. Journal of Global Entrepreneurship Research, 6(1), 8. https://doi.org/10. 1186/s40497-016-0051-1.

Alom, F., Abdullah, M. A., Moten, A. R., \& Azam, S. M. F. (2016). Success factors of overall improvement of microenterprises in Malaysia: An empirical study. Journal of Global Entrepreneurship Research, 6(1), 7. https://doi.org/10.1186/s40497-016-0050-2.

Ardichvili, A., Cardozo, R., \& Ray, S. (2003). A theory of entrepreneurial opportunity identification and development. Journal of Business Venturing, 18(1), 105-123. https://doi.org/10.1016/S0883-9026(01)00068-4.

Arora, P., Haynie, J. M., \& Laurence, G. A. (2013). Counterfactual thinking and entrepreneurial self-efficacy: The moderating role of self-esteem and dispositional affect. Entrepreneurship: Theory and Practice, 37(2), 359-385. https://doi.org/10.1111/j. 1540-6520.2011.00472.x.

Artinger, S., \& Powell, T. C. (2015). Entrepreneurial failure: Statistical and psychological explanations. Strategic Management Journal, forthcoming. https://doi.org/10.1002/smj.2378.

Avey, J. B., Luthans, F., \& Youssef, C. M. (2010). The additive value of positive psychological capital in predicting work attitudes and behaviors. Journal of Management, 36(2), 430-452. https://doi.org/10.1177/0149206308329961.

Avey, J. B., Reichard, R. J., Luthans, F., \& Mhatre, K. H. (2011). Meta-analysis of the impact of positive psychological capital on employee attitudes, behaviors, and performance. Human Resource Development Quarterly, 22(2), 127-152. https://doi.org/ 10.1002/hrdq.20070.

Baluku, M. M., Kikooma, J. F., \& Kibanja, G. M. (2016a). Does personality of owners of micro enterprises matter for the relationship between startup capital and entrepreneurial success? African Journal of Business Management, 10(1), 13-23. https://doi.org/10.5897/AJBM2015.7738.

Baluku, M. M., Kikooma, J. F., \& Kibanja, G. M. (2016b). Psychological capital and the startup capital - Entrepreneurial success relationship. Journal of Small Business \& Entrepreneurship, 28(1), 27-54. https://doi.org/10.1080/08276331.2015.1132512.

Bandura, A. (1997). Self-efficacy: the exercise of control. Choice Reviews Online (Vol. 35). Worth Publishers. https://doi.org/10 5860/CHOICE.35-1826.

Baron, R. A. (2000). Psychological perspectives on entrepreneurship: Cognitive and social factors in entrepreneurs' success. Current Directions in Psychological Science, 9(1), 15-18. https://doi.org/10.1111/1467-8721.00050.

Baron, R. A. (2006). Opportunity recognition as pattern recognition: How entrepreneurs "connect the dots" to identify new business opportunities. Academy of Management Perspectives, 20(1), 104-119. https://doi.org/10.5465/AMP.2006.19873412.

Baron, R. A., Franklin, R. J., \& Hmieleski, K. M. (2016). Why entrepreneurs often experience low, not high, levels of stress: The joint effects of selection and psychological capital. Journal of Management, 42(3), 742-768. https://doi.org/10.1177/ 0149206313495411

Baron, R. A., \& Markman, G. D. (2000). Beyond social capital: How social skills can enhance entrepreneurs' success. Academy of Management Perspectives, 14(1), 106-116. https://doi.org/10.5465/AME.2000.2909843.

Blau, G. J. (1985). The measurement and prediction of career commitment. Journal of Occupational Psychology, 58(4), 277-288, https://doi.org/10.1111/j.2044-8325.1985.tb00201.x.

Blau, G. J. (1988). Further exploring the meaning and measurement of career commitment. Journal of Vocational Behavior, 32(3), 284-297. https://doi.org/10.1016/0001-8791(88)90020-6. 
Blonska, A., Storey, C., Rozemeijer, F., Wetzels, M., \& de Ruyter, K. (2013). Decomposing the effect of supplier development on relationship benefits: The role of relational capital. Industrial Marketing Management, 42(8), 1295-1306. https://doi.org/10. 1016/j.indmarman.2013.06.007.

Bøllingtoft, A. (2012). The bottom-up business incubator: Leverage to networking and cooperation practices in a self-generated, entrepreneurial-enabled environment. Technovation, 32(5), 304-315. https://doi.org/10.1016/j.technovation.2011.11.005.

Bontis, N. (1998). Intellectual capital: An exploratory study that develops measures and models. Management Decision, 36(2), 63-76. https://doi.org/10.1108/00251749810204142.

Borg, S. W., \& Johnston, W. J. (2013). The IPS-EQ model: Interpersonal skills and emotional intelligence in a sales process. Journal of Personal Selling \& Sales Management, 33(1), 39-52. https://doi.org/10.2753/PSS0885-3134330104.

Bowers, M. R., \& Martin, C. L. (2007). Trading places redux: Employees as customers, customers as employees. Journal of Services Marketing, 21(2), 88-98. https://doi.org/10.1108/08876040710737859.

Boyatzis, R. E., \& Ratti, F. (2009). Emotional, social and cognitive intelligence competencies distinguishing effective Italian managers and leaders in a private company and cooperatives. Journal of Management Development, 28(9), 821-838. https://doi.org/10.1108/02621710910987674.

Boyd, N. G., \& Vozikis, G. S. (1994). The influence of self-efficacy on the development of entrepreneurial intentions and actions. Entrepreneurship Theory and Practice, 18, 63-77. https://doi.org/10.1080/02640410152475847.

Brandt, T., Gomes, J. F. S., \& Boyanova, D. (2011). Personality and psychological capital as indicators of future job success? A multicultural comparison between three European countries. Finnish Journal of Business Economics, 3(11), 263-289.

Bronzetti, G., \& Veltri, S. (2013). Intellectual capital reporting in the Italian non-profit sector: Analysing a case study. Journal of Intellectual Capital, 14(2), 246-263. https://doi.org/10.1108/14691931311323878.

Chen, Q., Wen, Z., Kong, Y., Niu, J., \& Hau, K.-T. (2017b). Influence of leaders' psychological capital on their followers: Multilevel mediation effect of organizational identification. Frontiers in Psychology, 8, 1776. https://doi.org/10.3389/fpsyg.2017.01776.

Chen, S., Joardar, A., \& Wu, S. (2017a). Emerging differently: An examination of entrepreneurial optimism in emerging economies. International Journal of Business and Emerging Markets, 9(4), 354. https://doi.org/10.1504/IJBEM.2017.087818.

Chen, S., Liao, Z., Redd, T., \& Wu, S. (2013). Laotian entrepreneurs' optimism and new venture performance. Social Behavior and Personality: An International Journal, 41(8), 1267-1278. https://doi.org/10.2224/sbp.2013.41.8.1267.

Chin, S. T. S., Raman, K., Yeow, J. A., \& Eze, U. C. (2012). Relationship between emotional intelligence and spiritual intelligence in nurturing creativity and innovation among successful entrepreneurs: A conceptual framework. Procedia - Social and Behavioral Sciences, 57, 261-267. https://doi.org/10.1016/j.sbspro.2012.09.1184.

Crowne, K. a. (2009). The relationships among social intelligence, emotional intelligence and cultural intelligence. Organization Management Journal, 6(3), 148-163. https://doi.org/10.1057/omj.2009.20.

De Meza, D., \& Southey, C. (1996). The borrower's curse: Optimism, finance and entrepreneurship. Economic Journal, 106, $375-386$.

Deci, E. L., \& Ryan, R. M. (2000). The "what" and "why" of goal pursuits: Human needs and the self-determination of behavior. Psychological Inquiry, 11(4), 227-268. https://doi.org/10.1207/S15327965PLI1104_01.

Deci, E. L., \& Ryan, R. M. (2015). Self-determination theory. In International Encyclopedia of the Social \& Behavioral Sciences (Vol. 23, pp. 486-491). Elsevier. https://doi.org/10.1016/B978-0-08-097086-8.26036-4

Deci, E. L., Ryan, R. M., Gagné, M., Leone, D. R., Usunov, J., \& Kornazheva, B. P. (2001). Need satisfaction, motivation, and wellbeing in the work organizations of a former eastern bloc country: A cross-cultural study of self-determination. Personality and Social Psychology Bulletin, 27(8), 930-942. https://doi.org/10.1177/0146167201278002.

DeTienne, D. R. (2010). Entrepreneurial exit as a critical component of the entrepreneurial process: Theoretical development. Journal of Business Venturing, 25(2), 203-215. https://doi.org/10.1016/j.jbusvent.2008.05.004.

Duening, T. N. (2010). Five minds for the entrepreneurial future: Cognitive skills as the intellectual foundation for next generation entrepreneurship curricula. Journal of Entrepreneurship, 19(1), 1-22. https://doi.org/10.1177/ 097135570901900101.

Feldman, D. B., \& Kubota, M. (2015). Hope, self-efficacy, optimism, and academic achievement: Distinguishing constructs and levels of specificity in predicting college grade-point average. Learning and Individual Differences, 37, 210-216. https://doi. org/10.1016/j.lindif.2014.11.022.

Gindling, T. H., \& Newhouse, D. (2014). Self-employment in the developing world. World Development, 56, 313-331. https:// doi.org/10.1016/j.worlddev.2013.03.003.

Goldsmith, A. H., Veum, J. R., \& Darity, W. (1997). The impact of psychological and human capital on wages. Economic Inquiry, 35, 815-829. https://doi.org/10.1111/j.1465-7295.1997.tb01966.x.

Gudmundsson, S. V., \& Lechner, C. (2013). Cognitive biases, organization, and entrepreneurial firm survival. European Management Journal, 31(3), 278-294. https://doi.org/10.1016/j.emj.2013.01.001.

Hayek, M. (2012). Control beliefs and positive psychological capital can nascent entrepreneurs discriminate between what can and cannot be controlled? Journal of Management Research, 12(1), 3-13.

Haynie, J. M., Shepherd, D., Mosakowski, E., \& Earley, P. C. (2010). A situated metacognitive model of the entrepreneurial mindset. Journal of Business Venturing, 25(2), 217-229. https://doi.org/10.1016/j.jbusvent.2008.10.001.

Hayes, A. (2013). Introduction to Mediation, Moderation, and Conditional Process Analysis. Guilford, Guilford Press, New York, NY.

Hirschfeld, R. R. (2000). Does revising the intrinsic and extrinsic subscales of the Minnesota satisfaction questionnaire short form make a difference? Educational and Psychological Measurement, 60(2), 255-270. https://doi.org/10.1177/ 00131640021970493.

Hmieleski, K., \& Baron, R. (2009). Entrepreneurs' optimism and new venture performance: A social cognitive perspective. Academy of Management Journal, 52(3), 473-488. https://doi.org/10.5465/AMJ.2009.41330755.

Hmieleski, K. M., \& Baron, R. A. (2008). When does entrepreneurial self-efficacy enhance versus reduce firm performance? Strategic Entrepreneurship Journal, 2(1), 57-72. https://doi.org/10.1002/sej.42.

Hmieleski, K. M., \& Carr, J. C. (2008). The relationship between entrepreneurs psychological capital and new venture performance. Frontiers of Entrepreneurship Research, 28(4), 1-15.

Hmieleski, K. M., \& Corbett, A. C. (2008). The contrasting interaction effects of improvisational behavior with entrepreneurial self-efficacy on new venture performance and entrepreneur work satisfaction. Journal of Business Venturing, 23(4), 482496. https://doi.org/10.1016/j.jbusvent.2007.04.002. 
Hobfoll, S. E. (2002). Social and psychological resources and adaptation. Review of General Psychology, 6(4), 307-324. https:// doi.org/10.1037/1089-2680.6.4.307.

Hobfoll, S. E. (2011). Conservation of resource caravans and engaged settings. Journal of Occupational and Organizational Psychology, 84(1), 116-122. https://doi.org/10.1111/j.2044-8325.2010.02016.x.

Hormiga, E., Batista-Canino, R. M., \& Sánchez-Medina, A. (2011). The impact of relational capital on the success of new business start-ups. Journal of Small Business Management, 49(4), 617-638. https://doi.org/10.1111/j.1540-627X.2011.00339.x.

Humphrey, R. H. (2013). The benefits of emotional intelligence and empathy to entrepreneurship. Erj, 3(3), 287-294. https:/ doi.org/10.1515/eri-2013-0057.

Jensen, S. M., \& Luthans, F. (2006). Relationship between entrepreneurs' psychological capital and their authentic leadership. Journal of Managerial Issues, 18(2), 254-273. https://doi.org/10.2307/40604537.

Kaukiainen, A., Björkqvist, K., Lagerspetz, K., Österman, K., Salmivalli, C., Rothberg, S., \& Ahlbom, A. (1999). The relationships between social intelligence, empathy, and three types of aggression. Aggressive Behavior, 25(2), 81-89. https://doi.org/10 1002/(SICI) 1098-2337(1999)25:2<81::AID-AB1>3.0.CO;2-M

Kim, M., Perrewé, P. L., Kim, Y. K., \& Kim, A. C. H. (2017). Psychological capital in sport organizations: Hope, efficacy, resilience, and optimism among employees in sport (HEROES). European Sport Management Quarterly, 17(5), 659-680. https://doi. org/10.1080/16184742.2017.1344284.

Kim, P. H., Aldrich, H. E., \& Keister, L. A. (2006). Access (not) denied: The impact of financial, human, and cultural capital on entrepreneurial entry in the United States. Small Business Economics, 27(1), 5-22. https://doi.org/10.1007/s11187-006-0007-x.

Kottwitz, M. U., Hünefeld, L., Frank, B. P., \& Otto, K. (2017). The more, the better?! multiple vs. single jobholders' job satisfaction as a matter of lacked information. Frontiers in Psychology, 8(JUL), 1-11. https://doi.org/10.3389/fpsyg.2017.01274

Lans, T., Blok, V., \& Gulikers, J. (2015). Show me your network and I'll tell you who you are: Social competence and social capital of early-stage entrepreneurs. Entrepreneurship \& Regional Development, 27(7-8), 458-473. https://doi.org/10.1080/ 08985626.2015 .1070537

Lee, D. Y., \& Tsang, E. W. K. (2001). The effects of entrepreneurial personality, background and network activities on venture growth. Journal of Management Studies, 38(4), 583-602. https://doi.org/10.1111/1467-6486.00250.

Liu, C. L. E., Ghauri, P. N., \& Sinkovics, R. R. (2010). Understanding the impact of relational capital and organizational learning on alliance outcomes. Journal of World Business, 45(3), 237-249. https://doi.org/10.1016/j.jwb.2009.09.005.

Luthans, F. (2012). Psychological capital: Implications for HRD, retrospective analysis, and future directions. Human Resource Development Quarterly, 23(1), 1-8. https://doi.org/10.1002/hrdq.21119.

Luthans, F., Avey, J. B., \& Patera, J. L. (2008a). Experimental analysis of a web-based training intervention to develop positive psychological capital. Academy of Management Learning and Education, 7(2), 209-221. https://doi.org/10.5465/AMLE.2008. 32712618.

Luthans, F., Avolio, B. J., \& Avey, J. B. (2007a). Psychological Capital (PsyCap) Questionnaire (PCQ). California, USA: Mind Garden, Inc.

Luthans, F., Avolio, B. J., Avey, J. B., \& Norman, S. M. (2007b). Positive psychological capital: Measurement and relationship with performance and satisfaction. Personnel Psychology, 60, 541-572.

Luthans, F., \& Jensen, S. M. (2002). Hope: A new positive strength for human resource development. Human Resource Development Review, 1(3), 304-322. https://doi.org/10.1177/1534484302013003.

Luthans, F., Luthans, K. W., \& Luthans, B. C. (2004). Positive psychological capital: Beyond human and social capital. Business Horizons, 47(1), 45-50. https://doi.org/10.1016/j.bushor.2003.11.007.

Luthans, F., Norman, S. M., Avolio, B. J., \& Avey, J. B. (2008b). The mediating role of psychological capital in the supportive organizational climate - employee performance relationship. Journal of Organizational Behavior, 29(2), 219-238. https:// doi.org/10.1002/job.507.

Luthans, F., Youssef, C. M., \& Avolio, B. J. (2007c). Psychological capital: Investing and developing positive organizational behavior. In D. Nelson \& C. L. Cooper (Eds.), Positive organizational behavior (pp. 9-24). London, UK: Sage publications. https://doi.org/10.4135/9781446212752.n2.

Luthans, F., \& Youssef-Morgan, C. M. (2017). Psychological capital: An evidence-based positive approach. Annual Review of Organizational Psychology and Organizational Behavior, 4(1), 339-366. https://doi.org/10.1146/annurev-orgpsych$032516-113324$.

Markman, G. D., \& Baron, R. A. (2003). Person-entrepreneurship fit: Why some people are more successful as entrepreneurs than others. Human Resource Management Review, 13(2), 281-301. https://doi.org/10.1016/S1053-4822(03)00018-4.

Markman, G. D., Baron, R. A., \& Balkin, D. B. (2005). Are perseverance and self-efficacy costless? Assessing entrepreneurs' regretful thinking. Journal of Organizational Behavior, 26(1), 1-19. https://doi.org/10.1002/job.305.

Masten, A. S. (2001). Ordinary magic: Resilience processes in development. American Psychologist, 56(3), 227-238. https://doi. org/10.1037//0003-066X.56.3.227.

Masterson, S. S. (2001). A trickle-down model of organizational justice: Relating employees' and customers' perceptions of and reactions to fairness. Journal of Applied Psychology, 86(4), 594-604. https://doi.org/10.1037//0021-9010.86.4.594.

Miller, A. (2012). Investigating social desirability bias in student self-report surveys. Association for Institutional Research, 36(1), 30-47.

Milyavskaya, M., \& Koestner, R. (2011). Psychological needs, motivation, and well-being: A test of self-determination theory across multiple domains. Personality and Individual Differences, 50(3), 387-391. https://doi.org/10.1016/j.paid.2010.10.029.

Munene, J. C., Kikooma, J. F., \& Nansubuga, F. (2015). People development: Promoting the solid and uncovering the young talent - The fulcrum of competitive advantage. Employer of the Year \& HR REVEAL Awards 2015. Kampala: Fedeartion of Uganda Employers (FUE).

Norman, S. M., Avey, J. B., Nimnicht, J. L., \& Graber Pigeon, N. (2010). The interactive effects of psychological capital and organizational identity on employee organizational citizenship and deviance behaviors. Journal of Leadership \& Organizational Studies, 17(4), 380-391. https://doi.org/10.1177/1548051809353764.

Nunnally, J. C. J. (1978). Psychometric theory. Auflage, New York: Mc Graw-Hill.

Page, L. F., \& Donohue, R. (2004). Positive psychological Capital: A preliminary exploration of the construct Department of Management Working Paper Series. October, 1(October), 1-10. https://doi.org/10.1002/job.

Paine, K. D., Katie, B., \& Paine, D. (2003). Guidelines for Measuring Trust in Organizations By Guidelines for Measuring Trust in Organizations, 13. 
Patel, P. C., \& Thatcher, S. M. B. (2014). Sticking it out: Individual attributes and persistence in self-employment. Journal of Management, 40(7), 1932-1979. https://doi.org/10.1177/0149206312446643.

Pollack, J. M., Vanepps, E. M., \& Hayes, A. F. (2012). The moderating role of social ties on entrepreneurs' depressed affect and withdrawal intentions in response to economic stress. Journal of Organizational Behavior, 33(6), 789-810. https://doi.org/ 10.1002/job.1794.

Qureshi, M. S., Aziz, N., \& Mian, S. A. (2017). How marketing capabilities shape entrepreneurial firm's performance? Evidence from new technology-based firms in Turkey. Journal of Global Entrepreneurship Research, 7(1), 15. https://doi.org/10.1186/ s40497-017-0071-5.

Rauch, A., Braennback, M., \& Carsud, A. L. (2010). Understanding the entrepreneurial mind: Opening the black box. International Small Business Journal, 28. https://doi.org/10.1177/0266242610371730.

Rego, A., Sousa, F., Marques, C., \& Cunha, M. P. e. (2012). Authentic leadership promoting employees' psychological capital and creativity. Journal of Business Research, 65(3), 429-437. https://doi.org/10.1016/j.jbusres.2011.10.003.

Riggio, R. E., \& Reichard, R. J. (2008). The emotional and social intelligences of effective leadership: An emotional and social skill approach. Journal of Managerial Psychology, 23(2), 169-185. https://doi.org/10.1108/02683940810850808.

Rigotti, L., Ryan, M., \& Vaithianathan, R. (2011). Optimism and firm formation. Economic Theory, 46(1), 1-38. https://doi.org/10 1007/s00199-009-0501-x.

Rindova, V., Barry, D., \& Ketchen, D. (2009). Entrepreneuring as emancipation. Academy of Management Review, 34(3), 477-491. https://doi.org/10.5465/AMR.2009.40632647.

Robb, A. M., \& Fairlie, R. W. (2009). Determinants of business success: An examination of Asian-owned businesses in the USA. Journal of Population Economics, 22(4), 1-32. https://doi.org/10.1007/s00148-008-0193-8.

Ryan, R. M. (2009). Self-determination Theory and Wellbeing. Wellbeing in Developing Countries, (June), 1-2.

Samman, E. (2007). Psychological and subjective well-being: A proposal for internationally comparable indicators. Oxford Development Studies, 35(4), 459-486. https://doi.org/10.1080/13600810701701939.

Sarwar, H., Nadeem, K., \& Aftab, J. (2017). The impact of psychological capital on project success mediating role of emotional intelligence in construction organizations of Pakistan. Journal of Global Entrepreneurship Research, 7(1), 22. https://doi.org/ 10.1186/s40497-017-0080-4.

Serrano-Cinca, C., Fuertes-Callén, Y., \& Mar-Molinero, C. (2005). Measuring DEA efficiency in Internet companies. Decision Support Systems (Vol. 38). New York: Guilford Press. https://doi.org/10.1016/i.dss.2003.08.004

Silvera, D., Martinussen, M., \& Dahl, T. I. (2001). The Tromso Social Intelligence Scale, a self-report measure of social intelligence. Scandinavian Journal of Psychology, 42(4), 313-319. https://doi.org/10.1111/1467-9450.00242.

Snyder, C. R. (2002). Hope theory: Rainbows in the mind. Psychological Inquiry, 13(4), 249-275. https://doi.org/10.1207/ S15327965PLI1304_01.

Snyder, C. R., Sympson, S. C., Ybasco, F. C., Borders, T. F., Babyak, M. A., \& Higgins, R. L. (1996). Development and validation of the state hope scale. Journal of Personality and Social Psychology, 70(2), 321-335. https://doi.org/10.1037/0022-3514.70.2.321.

Stagman-Tyrer, D. (2014). Resiliency and the nurse leader: The importance of equanimity, optimism, and perseverance. Nursing Management, 45(6), 46-50. https://doi.org/10.1097/01.NUMA.0000449763.99370.7f.

Stajkovic, A., \& Luthans, F. (1998). Social cognitive theory and self-efficacy: Going beyond traditional motivational and behavioral approaches. Organizational Dynamics.

Stewart, T., \& Ruckdeschel, C. (1998). Intellectual capital: The new wealth of organizations. Performance Improvement, 37(7), 56-59. https://doi.org/10.1002/pfi.4140370713.

Still, K., Huhtamäki, J., \& Russell, M. (2013). Relational capital and social capital: One or two fields of research? In Proceedings of the International Conference on Intellectual Capital, Knowledge Management \& Organizational Learning (pp. 420-428).

Storey, D. J. (2011). Optimism and chance: The elephants in the entrepreneurship room. International Small Business Journal, 29(4), 303-321. https://doi.org/10.1177/0266242611403871

Sweetman, D., Luthans, F., Avey, J. B., \& Luthans, B. C. (2011). Relationship between positive psychological capital and creative performance. Canadian Journal of Administrative Sciences, 28(1), 4-13. https://doi.org/10.1002/cjas.175.

Trevelyan, R. (2008). Optimism, overconfidence and entrepreneurial activity. Management Decision, 46(7), 986-1001. https:// doi.org/10.1108/00251740810890177.

Tumasjan, A., \& Braun, R. (2012). In the eye of the beholder: How regulatory focus and self-efficacy interact in influencing opportunity recognition. Journal of Business Venturing, 27(6), 622-636. https://doi.org/10.1016/j.jbusvent.2011.08.001.

Tushabomwe-Kazooba, C. (2006). Causes of small business failure in Uganda: A case study from Bushenyi and Mbarara towns. African Studies Quarterly, 8(4), 27-35.

Umukoro, O. S., \& Okurame, D. E. (2017). Exogenous determinants of entrepreneurial intuition and the mediatory role of psychological capital among potential youth entrepreneurs. Journal of Global Entrepreneurship Research, 7(1), 19. https:// doi.org/10.1186/s40497-017-0078-y.

Vansteenkiste, M., Neyrinck, B., Niemiec, C. P., Soenens, B., De Witte, H., \& Van Den Broeck, A. (2007). On the relations among work value orientations, psychological need satisfaction and job outcomes: A self-determination theory approach. Journal of Occupational and Organizational Psychology, 80(2), 251-277. https://doi.org/10.1348/096317906X111024.

Walker, E., \& Brown, A. (2004). What success factors are important to small business owners? International Small Business Journal, 22(6), 577-594. https://doi.org/10.1177/0266242604047411.

Williams, H. W. (2008). Characteristics that distinguish outstanding urban principals: Emotional intelligence, social intelligence, and environmental adaptation. Journal of Management Development, 27(1), 36-54. https://doi.org/10.1108/ 02621710810840758.

Wilson, F., Kickul, J., \& Marlino, D. (2007). Gender, entrepreneurial self-efficacy, and entrepreneurial career intentions: Implications for entrepreneurship education. Entrepreneurship: Theory and Practice, 31(3), 387-406. https://doi.org/10.1111/ j.1540-6520.2007.00179.x 